\title{
A Critical Narrative of the Anderson Theory of Imagined Community: An Indonesian Perspective
}

\author{
Pratiwi Cristin Harnita ${ }^{1}$, Putri Hergianasari ${ }^{1}$, Jamilah Ahmad, PhD $^{2^{*}}$, Dewi Kartika Sari ${ }^{1}$ \\ ${ }^{1}$ Lecturer at Faculty of Social Science and Communication Science, Universitas Kristen Satya Wacana \\ ${ }^{2}$ Professor at School of Communication, Universiti Sains Malaysia
}

*Corresponding Author: Jamilah Ahmad, PhD, Professor at School of Communication, Universiti Sains Malaysia

\begin{abstract}
This article critically discusses the Anderson's theory of the imagined community, which is based on Anderson's interest in Kahin and Benjamin's theory of nationalism which was developed in 1959. This article discusses based on interpretation of imagined communities' perspectives by Anderson on four characteristics which are nation building, imagine, limited, sovereign and community. This article also discusses the criticisms of several authors regarding Anderson's theory which is interpreted by his commentator as lacking in explaining the concept of nation. Anderson's theory was also criticized as not being applicable to the Indonesian context of media before and after the cyber era. Despite criticism, Anderson's thoughts on Imagined Communities are still the subject of study by many scholars in Indonesia and in South East Asia. This article aims to add to the body of knowledge and perspectives to Anderson's Theory for both references and clarity of the endless argument about Imagined Communities perspectives, which concept is currently called as Cybernationalism.
\end{abstract}

Keywords: Benedict Anderson, Imagined Community, Indonesia, Cybernationalism

\section{INTRODUCTION}

Benedict Richard O'Gorman Anderson was born in Kunming, China on August 26, 1936 . A renowned professor in the field of international studies at Cornell University, he is often called Ben Anderson who is a political expert and historian. Anderson also referred to as an Indo-chianist although of Jewish descent, had paid great attention to Javanese culture. His thinking about nationalism was talked about after he published the best-seller book titled "Imagined Unities" in 1983 which is still printed until today. He claimed that the Marxist approach as a factor in the emergence of nationalism in the world. He also analyzed critically about Indonesia and the government of Indonesia until he was banned from entering Indonesia during Suharto's regime.

Anderson was banned by Suharto's regime after he released a controversial book titled "The Cornel Paper" which gave a new perspective about the September 30th movement coup which involved the murder of generals by the Indonesian Communist Party. However, after Suharto collapsed, he returned to Indonesia and stayed in Indonesia until he died at the age of 79 on December 12, 2015, in Batu City Malang district (www.sindonews.com, 2015).

\section{THE INFLUENCED OF KAHIN AND BENJAMIN}

Anderson in his book Imagined Communities stated that colonialism and imperialism are extreme forms of the first wave nationalism. George Kahin's work influenced Anderson's thoughts on issues related to nationalism and revolution in Indonesia. Although George Kahin's work did not philosophically define nationalism, he implicitly defined the meaning of nationalism through the clash of ideas of the elites as the driving force to Indonesian revolution that opposed colonialism and imperialism [1]. Kahin viewed Indonesian nationalism as elite nationalism and the nationalist thinking of the elitist group was the result of education influence from the West of which Kahin felt the need for Indonesia to fight western colonialism. However, Kahin's works subsided the role of leftists during the revolution in Indonesia, which resulted in unbalanced argument on his findings.

According to Anderson, Kahin's idea of nationalism began to move his narrative. Anderson perceives that the shift of actors during the revolution changed the concept of elite nationalism to youth 
nationalism in Indonesia. The Youth Oath event according to Anderson played an important role in strengthening the role of language as a means of national unity that created the Imagine Community. Nationalism is no longer what the elites had perceived but was driven by the youth. Anderson added that nationalism is an engagement of people from different regions and different backgrounds who have a common language as a means of the Imagine Community.

In Imagined Communities, the adhesive language for nationalism in colonized nations is created by colonial governments. Nationalism in postcolonial countries such as Indonesia is the opposite of Europe. Nationalism in Europe developed because of the erosion of Latin as the Lingua Franca and the rise of vernacular language classes due to the development of print capitalism. Nationalism in postcolonial countries like Indonesia took the path of eliminating diverse vernacular topics and establishing a unifying language, namely the national language.

Nationalist thinking in the Imagine Community book written by Benedict Anderson became a phenomenal work most referred by scholars in Southeast Asia because Anderson applied Marxist approach as a factor that led to the emergence of nationalism in the world. Anderson wrote that the main cause of the emergence of nationalism and the formation of imagined communities was the lack of special access to certain written languages, besides the movement to eliminate the idea of divine government and monarchy, and the emergence of printing machines by capitalism which Anderson referred to as "print capitalism ". Anderson also initiated nationalism which was formulated through a revolution that moved in stages, namely moving on European countries, Creole countries, Asia and Africa.

Anderson's work was also influenced by Benjamin Walter who looked at mechanical reproduction. Benjamin's views on materialism, culture and politics in the modern era inspired Anderson. Benjamin's understanding of origin and spread of nationalism are as: (1) the importance afforded to print-capitalism; (2) the relation between homogeneous, empty-time, modernity and nationalism; and image of the history [2].

The inception of books and the newspaper industry accompanied by the rapid growth of capitalism was the beginning of European nations to find their nationalism. Anderson revealed the emergence of nationalism in Europe along with the emergence of the language revolution and print capitalism. The discovery of nationalism in ex-colonial countries was marked by the emergence of a "new world", which was a form of the nation-state resistance that had been colonized. The idea of nationalism in ex-colonial countries was determined by colonialism and it was unintentional. It was used as an effort to free themselves from exploitation of humans and nature in the name of capitalism. The role of language used by the invaders was used as a means to fight for nationalism.

\section{ANDERSON'S THEORY OF NATIONALISM: IMAGINED COMMUNITIES}

In imagined communities, Anderson defines the state and the spread of nationalism. According to Anderson, the state is an imagination of the political community which is territorial and state. The community is imagined as a horizontal community without regard to hierarchical reality and is a cultural artifact and not a political ideology. Anderson also tried to explain the history of nationalism movement without questioning whether nationalism ideology adapted is genuine.

To understand nationalism, Anderson explained that a nation is an Imagined Community and divided it into four categories. First, assuming that not all members known each other although in their minds they aware of the importance of partnership. Second, there is always a territorial boundary that limits or separates one nation from another. Third, community defined as sovereign community meaning the nation has concepts and rules that apply in its territory such as constitution, language, national anthem, national symbol etc. Fourth, the nation is perceived as a community because even though in reality the community is characterized by various differences, but the nation is always understood as a strong and deep brotherhood [3].

Anderson's thought about the community is also similar to Ernest Gellner's. According to Gellner, the developed nationalism is the one that respects humanity and differences with no discrimination practices and must be productive for human values. Understanding nation according to Gellner (1998) [4] is a condition of a community with similar culture, symbols, systems, ideas including ways of behaving and communicating. This community is bound by brotherhood on the basis of nationality. Anderson and Gellner's perspectives show similarities in defining nationalism. The only different is Gellner describes nationalism as fake phenomenon, but in Anderson's thinking, imagined 
communities showed that nationalism and the nation had their own values which were shown by the individuals in them. These individuals then consider themselves as part of the community.

\section{CRitics OF THEORY}

The theory put forward by Anderson was criticized by several scholars. Anderson said "communities are being differentiated by the style in which they are imagined" [5]. However, according to some scholars the concept of imagined community fails to define the concept of community and the nation itself. The theory of imagine communities has not been able to distinguish one community with the other and Anderson theory emerged in the modern era could not be applied to the pre-modern era. Roland Robertson (2011) [6] echoes Holton (2008) stated that imagination, or imagining, was secondary to social economic relationships. It is more concern with networks, which were often regarded as the foundation of awareness in culture objective. Robertson perceives Anderson Theory as phenomenologically impossible because Anderson is trying to fit his idea in local context to be applied in a global context. Robertson argued that although we tend to assume that the local is conscious, so to speak, but the global is distant and one cannot "imagine" a locality in the context of global of vice versa.

Anderson also assumed that different historical backgrounds gave different understandings for every nation and country. The Southeast Asian region has experienced foreign colonialism, so it has the urge to get out of trouble. Especially when the countries in Southeast Asia began to form movements of nationalism due to the pressure of economic crush, social and political pressure after being invaded by western countries during the 19 th and $20^{\text {th }}$ century.

\section{IMAGINED COMMUNITY BEFORE CYBER ERA: AN INDONESIAN CONTEXT}

Four characteristics of nation formation based on Anderson's thoughts in Indonesia, namely:

\subsection{Imagine}

In Indonesia, understanding of the imagined community shows that nationalism is constructed and inhabits the hearts and the hearts of the people. Anderson's first characteristic is imagine that is a political community which is horizontal, both limited and sovereign. "It is not only the most important thing to do, it will never know most of their fellow members, meet them, or even hear them, yet they live in the image of the communion." [3]. In the context of nationality in Indonesia, there are 267 million people with 1,340 ethnic groups (based on a survey of statistical center bodies in 2019).

\subsection{Sovereign}

The construction of nation ideology through tagline "Jiwa Pancasila" (Nationalist Soul) was pinned since primary school in Indonesia and also embedded in the curriculum, inherited in cultural and artistic values. Someone became nationalist when he or she recognized Pancasila as the basis of the State. Pancasila as the nation's ideology that is mutually agreed upon as a state foundation formulated by the founding fathers of the nation. In addition to Indonesian as a unifier, it is called the Unitary State of the Republic of Indonesia (NKRI) which describes the homeland.

\subsection{Limited}

In Indonesia, limited concept refers to territories and demographics that have been divided into provinces. Indonesia has thirty-five provinces inhabited by various ethnic, ethnic and religious groups. In this context, Indonesia is limited to the place of residence and origin of one's area.

\subsection{Community}

The characteristic of the community is attachment. "Javanesse villagers have always known that they are connected to people they have never seen, but these ties were once imagined in particular ways-as independent stringent network of kinship and clientship (ibid, p. 49). Anderson also saw nationalism as a cultural artifact. The construction of the Beautiful Indonesia Miniature Park (TMII) in Jakarta, which was initiated by Ms. Tien Soeharto, is an authentic Indonesian miniature with an eclectic mix of ethnicities. TMII is one of the cultural artifacts of the modern Indonesian society. This is a symbol of nationalism from the diversity of the Indonesian nation that is united. Indonesia scholars wrote several reflections on Anderson's work and linked them to the lives of urbanists in Indonesia. Rita Padawangi (2016) [7] in her reflection on Anderson's theory described urban life in Indonesia in an urban context, the city can be seen from a scale smaller than the state as Anderson did. Rita tries to 
see from the city realm, Jakarta. Jakarta is known as the Indonesian storefront. Although the native tribes of Jakarta are Betawi, Jakarta exceeds one tribe. Jakarta belongs to all citizens because Jakarta is the capital city of Indonesia. Rita added that Jakarta transformed into a megapolitan city with various tribal crossings, regions and even nations. Jakarta's community was transformed into an imagined community. Tens of millions of people live in Jakarta, and the average population also does not know the surroundings. The identity of Jakarta people is recognized from the existence of "Identity Cards." The author sees that not only Jakarta has experienced urbanization, other cities in Indonesia have become other imagined communities. In a much larger country, this imagined community is called a nation that is united by the spirit of nationalism.

According to Koh Young Houn (2012) [8], on his analysis on Pramodya Ananta Toer work on Nationalism and the Community Imagined showed that there is a connection between nationalism and cultural systems. Long before nationalism was spread through cyberspace, nationalism was first carried out by conventional methods. Discoveries of many write-ups in the form of articles and fictional writings from novels. Print media played an important role in the beginning of the birth of nationalism in Indonesia. Pramoedya Ananta Toer, a novelist who was banished to the island of Buru because of his writings were considered dangerous, is now realized to imply many things about nationalism. In a number of reviews, Author Pramoedya was also a pen pal to Anderson.

In Indonesia nationalism unites through political geographical conditions. Indonesia is often called an archipelago that has many tribes, and language differences. In Southeast Asia, nationalism also emerged in colonized countries due to democratic thinking. Nationalism was constructed by politicians as their agenda to strengthen the sense of brotherhood. The long history of the nation's struggle for independence gives the power to be able to maintain and defend each other. Quoting Anderson's writings in his book Imagined Communities, he stressed that far-reaching print media had an important role in the spread of nationalism.

"Perhaps there is no greater role in the beginning of this search, nor is there more fruit than print capitalism, because it allows a growing number of people to ... and associate themselves with each other in extraordinary new ways [9].

It can be concluded that the real nation is imagined communities, fellow citizens who do not know each other and are separated by distance. But this imagined community has the same shadow about a nation which is then channeled by the development of print media capitalism. Anderson claimed that mass printing became the media for the formation of national languages. This is not in line with Adisusilo (2010) [10], that language is not the basis for nation formation. Whereas in the context of nationalism in Indonesia, language is the starting point for the spread of nationalism.

America had 13 colonies, including Britain, but ultimately cut ties and immediately declared itself a nation that had sovereignty. By harnessing the power of the print media, making the nation which originally comprised small colonies, established itself as a country called America. This nationalism model was eventually emulated by European countries. According to Adisusilo, Anderson theory on community imagined is very unique. Nation as an imagined community in which there are differences in language, ethnicity, history and other attributes, but the form of awareness about nationalism can be the same. This map of Anderson's thinking about the nation and nationalism can be drawn on a universal template. Anderson also compared the formation of nationalism in the western and eastern countries. Imagined communities help Indonesian scholars to understand where nationalism came from.

After recognizing the power of the print media, rapidly developing technologies such as radio and television had greater influence. The mass media channel has a big influence in the process of diffusion of the values of nationalism in the society. According to hereditary stories, nationalists mobilized unity and unity from the west to the east, echoing the "mutual spirit of unity" through electronic media namely the radio. Long before independence was achieved, nationalists mobilized patriotic actions which were interpreted together as an agreement over differences. In 1928, ethnic and cultural differences in Indonesia were not an obstacle to unity, namely the emergence of the Youth Pledge. In the oath, there are three things that unite namely language, nation and homeland. This is a historic moment before the Indonesian independence was declared. In the moment of the youth oath, young people from various tribes fought for Indonesian independence. A long and fruitful struggle until 1945 Indonesia gained its independence. The imagined community described by Anderson later appeared in a sense of nationalism which was promoted from the Speech of Sukarno and echoed the songs of Indonesia Raya throughout the country through radio channels. 
Radio as a communication medium played an important role. The broadcast was heard throughout the country. As time went on, the State of Indonesia had passed a critical period after the colonial power transition. Indonesia became a fully sovereign country as the Unitary State of the Republic of Indonesia. Not only radio, now echoes of nationalism also appear on television, such as observations written by Enric Castelo (2016 p.61) [11] in a journal entitled "Anderson and Media" namely:

"The creation and distribution of given national" imaginary "is based on the construction of a given national imagined community that has certain traits (language, history, heroes, symbols and so on) and ignored others. One should, therefore, the importance for so called stateless nations of having access to the technology that is needed to be imagined by the community and the distinction that should be drawn from the technology (for example, a public television channel) and the symbolic broadcast content. Such content may only be replicated of the imagined community subordinated to a "superior." (ibid, p 61)

In the development of communication technology in Indonesia, people now have entered the digital era. The call for nationalism has also spread in the realm of the digital media. With the spread of nationalism in the realm of the digital media, it is called cyber nationalism. According to Dewi Kartika dan Ester (2017) [12] the spread of nationalism later formed in tribal communities, namely the Batak, Dayak, Balinese and Maluku tribes. In her findings she concluded that several ethnic communities were able to form new communities in the form of facebook groups which indicated that nationalism can be spread through Facebook which lead to the formation of a bigger community like what was mentioned in the theory of Benedict Anderson. Anderson concept of imagined community does help scholars to map out research plans about the spread of nationalism in the digital world. Again, one can question if Anderson's thoughts are relevant to explain nationalist communities in the digital world or currently known as Cybernationalism.

\section{IMAGINED COMMUNITY IN CYBER ERA}

Anderson emphasized the importance of nationalism. In the first millennium, Anderson had seen that there was a possibility of "nationalism deficits" where the national spirit was diminishing, especially for those rich and educated [9]. According to Anderson, the Indonesian people must regain the spirit of nationalism such as the period. Anderson insinuated the idea of "populist nationalism" which has a basic characteristic, namely the growing sense of belonging and affinity as a nation.

After Anderson's death, Kurniawan (2015) [13] gave Anderson's response to the political and economic elite in Indonesia. Anderson's suspicion of the political elite and its relation to the stretch of the Indonesian economy is accepted. Heryanto also criticized many facts about corrupt officials and cronyism. According to Heryan to nationalism formed in Indonesia cannot be equated with nationalism in other countries because Indonesia has its own character and is derived from a long history.

Anderson saw that the political elites at this time were different from their predecessors. Political elites no longer have a nationalist spirit. This phenomenon of nationalism deficit was also responded to by historian Taufik Abdulah (Kompas, August 18, 2007) and echoes by Adisusilo (2010) [10] as saying that the Indonesian nation must return to solidarity nationalism. Nationalism of solidarity is a return to a sense of responsibility as a citizen and as a part of a nation. The fading of nationalism began to appear in the community and the political elite with a non-nationalist attitude was obviously shown by the political elites in their lives and attitudes towards politics.

According to the observations by writers who have lived in the contemporary digital era, nationalism has been eroded in response to the disappointment towards the political elites, dissatisfaction with the economy and religious doctrine which is quite substantial in the Indonesian society. The results of modernization and the success of democratic thinking had made life easier in many ways. The technological revolution, the ease of access, according to the author, are factors that have made people to neglect and to maintain the sense of nationalism. Adisusilo (2010) [10] echoed based on English historian Arnold Toynbee (1956) who said that a nation would only progress if it could face challenges with the right response. Concern about the loss of the spirit of nationalism due to the success of democracy has made people less able to interpret the spirit of the early nationalist movements.

This is the thing that is feared in the digital era which is better known as era 4.0, and now we are facing the era of 5.0. Citizens in nation states are no longer considered a nation of a country that have a common home in diverse lives but more on the same orientation in terms of the economy. 


\section{Digital CiTIZENSHIP AND CYBERNATIONALISM}

In recent years, many people have begun to question the idea of "nationalism." In this new era, nationalism also means citizenship. Today's digital citizenship appears. Digital citizenship shows that in a sociological way of communication, modernization raises a much more modern feature of a new society. Today a person's life can be seen from his digital footprint. Digital citizenship arises from the phenomenon of the information society. The information society was then put forward by Castello (1998) in his book entitled Age: Economy, Society and Culture "called the network society. Castell expressed his views on the new society, culture and economy from the view point of the information technology revolution (television, computers, the internet, etc.).

When quoting Castello's thinking, the information society has tremendous network strength. There are five basic characteristics of information technology that presently affect all aspects of life including influencing national values and nationalism, namely information technology reaction to information; information as part of human activity, it has a pervasive effect; all systems have network logic, information technology is very flexible and can be adapted. Information technology that is most closely related to modern society today is the internet. The digital communication platform is a storehouse of information, and communication networks that allow the distribution of messages very quickly.

Anderson claims that print media capitalism in his book is no longer applicable in the current era of print media in Indonesia. The capitalism concept coined by Anderson was considered extraordinary during his time, however in the current digital age, the perspectives about print media has changed. In the past, nationalism was spread through the print media, but now the role of digital media is very influential. Communication networks in the digital world can transcend boundaries, time and space, which spread information very quickly at the same time.

Communities are said to be imagined communities, have the same feeling even though they do not know each other. Digital societies are alien to one another too however, because social networks are connected easily and connection are borderless. With the digital media, one can connect with societies in any part of the world. Therefore, Anderson's concept on imagined communities can be challenged and seems to be deem away from the reality due to social media and social networks that are available and easy access. At the same time, although digital network is borderless, a lot of content that is intentionally built to maintain a sense of national solidarity can still be maintained. Therefore, in this context, the "Indonesian-ness" can be maintained.

Calls for nationalism are now buzzing with the digital society. This is a response from insecurity with the discourse that "the country will disband" as the Indonesian politician Parbowo Subianto in his recent statement during the election of Presidency seat . The anti-NKRI movement such as Hizb utTahir Indonesia (HTI), the Islamic Defenders Front (FPI) and its culmination, Ahok case (Governor of Jakarta in the case of blasphemy) led to the 212 mass movement in downtown Jakarta. Anti-NKRI organization mobilized all their effort using communication networks via digital media. Anti=NKRI is able to form gathering to meet up with concerned societies in the center of Jakarta and they managed to get 7 million people to attend this gathering.

Although, there are many sites banned by the government because they have radical content and are not pro-Republic of Indonesia (NKRI). The anti-socialist radicalism spores also appears in both digital and in real life. There are several community forums that loudly call for a "khilafah state (Islamic Leaderdship State)" which is contrary to Pancasila (Foundational Philosophy of Indonesia). Pancasila is known as the philosophy of life of the Indonesian people. The Indonesian government actively highlighted how the development of radicalism is the opposite of nationalism. Therefore, currently the government has a cybercrime division to monitor and decide on radical networks that are developing using digital media due to fear of negatives ideologies brought by the anti-nationalist community which can influence the nationalist community that had been formed. This is one of the challenges in maintaining national ideology in the State of Indonesia.

\section{CONCLUSION}

Anderson's divide imagined communities in four characteristics that form a nation, namely imagine, sovereign, limited and community. Although Anderson's work was influenced by his predecessors, Kahin and Benjamin, ultimately imagine community nationalism theory was applied in various 
national contexts and countries in Southeast Asia, specifically in Indonesia. Anderson's thoughts were not free from criticism because it is considered to have failed to define the nation itself. Community imagined originated from mechanical reproduction which contribute to print capitalism, then values of nationality, unity increasingly developed during the era of print, radio, and television. Now digital communities are actively spreading the values of nationalism which coined the term of Cybernationalism as aspirations are discussed openly in many digital platform such as in social network forums, Facebook and other digital sites. Currently nationalism ideology in Indonesia was also brought in through code and symbol for example through hasgtag \# as an ld to promote nationalism movement such as \#NKRI price tag. Hastag is becoming Twitter's trending topic in Indonesia which raised nationalism movements in blogs and websites which were then widely disseminated and viral through digital platforms which also known as Cybernationalism.

\section{REFERENCES}

[1] Kahin. G.McT. 1959. Nationalism and Revolution in Indonesia. Ithaca, New York: Comell University Press

[2] Aylor, Antony. 2016. The Influence of Walter Benjamin. http.artonline.monash.edu.au/Indonesianstudies/Te-influence-of-Walter-benjamin.pdf. (accessed 2019-5-5)

[3] Anderson, benedict, 2006. Imagined Communities: Reflection on the Origin And Spread of Nationalism. London. Verso

[4] Gellner, E. (1998). Nationalism, London. Phoenix. Guilford

[5] Anderson, Benedict, 2008, Imagined communities: Reflections on the Origin and Spread of Nationalism, edisi Bahasa Indonesia Komunitas-komunitas Imajiner: Renungan tentang Asal Usul dan Penyebaran Nasionalisme, translated by Omi Intan Naomi, Pustaka Pelajar, Yogyakarta

[6] Roland Robertson (2011) "Global Connectivity and Global Consciousness", American Behavioral Scientist, Vol.55, no. 10, p.1336-1345

[7] Padawangi, Rita .2016. Benedict Anderson: A Reflection by an Indonesian Urbanist. Sage Publication. https://doi.org/10.1177/0263276416667201, p. 329-333.

[8] Koh Young Hun .2012. Nasionalisme dan Komuniktas Terbayang Dalam Karya-karya Novel Pramoedya Ananta Toer. Proceeding ICSSIS. 59-70. https://icssis.files.wordpress.com/2012/05/0609082010_08.pdf (accesed 2019-4-17)

[9] Anderson, Benedict, 2001, Imagined Communities: Komunitas-Komunitas Terbayang Yogyakarta: INSIST -Pustaka Pelajar

[10] Adisusilo, Sutarjo.2009. nasionalisme-Demokrasi-Civil Society. PDF. Jurnal. Vol. 123, p.1-15

[11] Castelo, enrich. 2016. Anderson and The Media. The Streght of Imagined Community. PDF Journal. DEBATS · Annual Review, 1, ISSN 2530-8262 (electronic), p. 59-63.

[12] Dewi Kartika, Sari and Ester, Krisnawati, E., 2017. The Spread of Nationalism using Social Media. Jurnal Ilmu Komunikasi, 15(3).

[13] Kurniawan, Hasan. 2015. Ben Anderson dan Kudeta Militer. Sindo Newas. 2015-12-25 https://daerah. sindonews.com/read/1070825/29/ben-anderson-dan-kudeta-militer-1-oktober-1965-1450531588 (accessed 2019-5-5)

Citation: Pratiwi Cristin Harnita, Jamilah Ahmad, PhD, et.al. "A Critical Narrative of the Anderson Theory of Imagined Community: An Indonesian Perspective". International Journal of Media, Journalism and Mass Communications (IJMJMC), vol 5, no. 3, 2019, pp. 45-51 doi: http://dx.doi.org/10.20431/2455-0043.0503005

Copyright: () 2019 Authors. This is an open-access article distributed under the terms of the Creative Commons Attribution License, which permits unrestricted use, distribution, and reproduction in any medium, provided the original author and source are credited. 